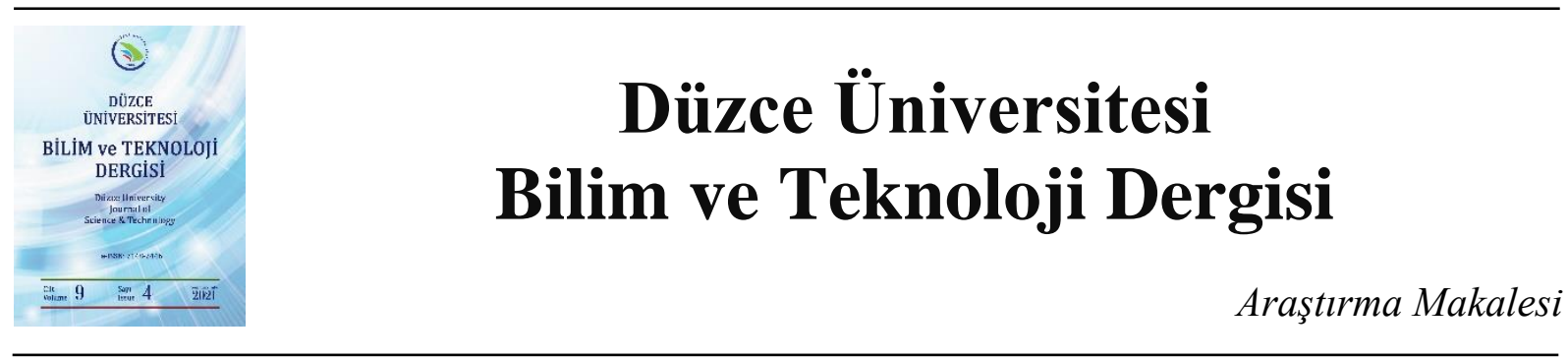

\section{Özel Sektör Çalıșanlarında İş Kazası ve Meslek Hastalıklarında Maliyet Analizi: Düzce İli Örneği}

\author{
Harun GÖRGÜN ${ }^{\mathrm{a}, *}$, (D) Tarık GEDIK ${ }^{\mathrm{b}}$ \\ ${ }^{a}$ OEM Bölümü, Orman Fakültesi, Düzce Üniversitesi, Düzce, TÜRKIYY \\ ${ }^{b}$ OEM Bölümü, Orman Fakültesi, Düzce Üniversitesi, Düzce, TÜRKIYE \\ *Sorumlu yazarın e-posta adresi: harungorgun1905@gmail.com \\ DOI: $10.29130 /$ dubited. 892751
}

\begin{abstract}
Öz
İşyerinde gerek çalışan gerekse de işveren tarafından iş sağlığı ve güvenliği önlemlerinin alınamaması nedeniyle iş kazaları meydana gelmektedir. Mesleki risklere maruziyet sonucu ortaya çıkan hastalıkların sonucu olarak da meslek hastalığı tanımı yapılmaktadır. Bu çalışma ile iş kazası ve meslek hastalığı nedeniyle Düzce ili Sosyal Güvenlik Kurumu (SGK) hastanelerinden yararlanan özel sektör çalışanlarının çalışanlara, işverenlere, kamu hastanelerine ve topluma maliyetleri hesaplanmıştır. Yapılan değerlendirmeler sonucunda Düzce kamu hastaneler birliği hastanelerine iş kazası ve meslek hastalığı nedeniyle müracaat edenlerin sayısının yıllar itibarıyla artı̧̧ gösterdiği belirlenmiştir. İş kazası nedeniyle ağırlıklı olarak 21-25 yaş grubundan, meslek hastalığı nedeniyle de ağırlıklı olarak 36 yaş ve üzeri çalışanların olduğu belirlenmiştir. İş kazası nedeniyle hastanelere müracaat eden hastaların ortalama 8 dakika 14 saniyede muayene oldukları hesaplanmıştır. Yapılan hesaplamalar sonucunda hastaların ortalama 29 dakika 50 saniye poliklinikte tedavi gördükleri ve ortalama 38 dakika 2 saniye de hastanede kaldıkları belirlenmiştir. 2010-2014 yılları arasında Düzce kamu hastaneler birliğine iş kazası ile müracaat eden hastaların büyük çoğunluğunun el ya da kol yaralanmalarından ve ayak ya da bacak yaralanmalarından kaynaklı şikâyetle müracaat ettikleri belirlenmiştir. Yapılan değerlendirmeler sonucunda iş kazası nedeniyle hastalara ortalama 4 gün rapor düzenlendiği belirlenmiştir. 2010-2014 yılları arasında iş kazasından kaynaklı olarak yıllara bağlı ortalama toplam maliyetler minimum 339,10 TL, maksimum da 447,72 TL olarak hesaplanmıştır.
\end{abstract}

Anahtar Kelimeler: Düzce, İs kazası, meslek hastalığı, sosyal güvenlik kurumu.

\section{Cost Analysis in Work Accidents and Occupational Diseases in Private Sector Employees: The Case of Duzce Province}

\begin{abstract}
Occupational accidents occur because occupational health and safety measures cannot be taken by both the employee and the employer in the workplace. The definition of occupational disease is also made as a result of diseases that occur as a result of exposure to occupational risks. With this study, the costs of private sector employees who benefit from Duzce Province Social Security Institution hospitals due to occupational accidents and diseases to employees, employers, public hospitals and society were calculated. As a result of the evaluations made, it was determined that the number of people who applied to Duzce public hospitals association hospitals due to work accidents and occupational diseases increased over the years. It has been determined that there are mainly employees in the 21-25 age group due to occupational accidents and 36 years and above due to occupational diseases. It has been calculated that patients who apply to hospitals due to work accidents are examined in an average of 8 minutes and 14 seconds. As a result of the calculations, it was determined that the patients were
\end{abstract}


treated in the outpatient clinic for an average of 29 minutes and 50 seconds, and that they stayed in the hospital for an average of 38 minutes and 2 seconds. It was determined that the vast majority of patients who applied to Duzce Public Hospitals Association with an occupational accident between 2010 and 2014 applied with complaints of hand or arm injuries and foot or leg injuries. As a result of the evaluations made, it was determined that patients received reports for an average of 4 days due to occupational accidents. Between 2010 and 2014, the average total costs depending on the years due to the occupational accident were calculated as a minimum of $339.10 \mathrm{TL}$ and a maximum of $447.72 \mathrm{TL}$.

Keywords: Duzce, Occupational disease, Social security institution, Work accident.

\section{GIRIS}

İş kazası ve meslek hastalığı konusunda literatürde birçok tanıma yer rastlanmaktadır. Gerek Dünya Çalışma Örgütü (ILO) gerekse de Dünya Sağlık Örgütü çalışanları tarafından yapılan iş sağlı̆̆ı ve güvenliği tanımlarında ortak nokta herhangi bir işte çalışan işçilerin, fiziksel, ruhsal ve sosyal yönden iyi olmalarının sağlanması ve bu durumun sürekli iyileştirilmesi; çalışma koşullarının işçilerin sağlıklarını kaybetmelerini önleyecek şekilde ve sürekli olarak iyileştirilmesi; işçilerin sağlıklarını olumsuz etkileyecek çalışma ortamlarından korunmalarını sağlayacak önlemlerin alınmasını; işçilerin hem fizyolojik hem de psikolojik yapılarına uygun işleri yapmaları gerektiği üzerinde odaklanmaktadır.

Literatürde iş kazası "sigortalının, işveren otoritesi altında bulunduğu bir sırada gördüğü iş veya işin gereği dolayısıyla aniden ve diştan meydana gelen bir etkenle onu bedence ya da ruhça zarara uğratan olay" şeklinde tanımı yaygın olarak geçmektedir [1-5].

İş hayatında iş kazaları ve meslek hastalıklarının önlenmesi hukuken zorunlu olmasına karşın her yıl milyonlarca çalışan hayatını kaybetmektedir. ILO verilerinde her 15 saniyede bir çalışanın iş kazası veya meslek hastalığına maruz kalmasından dolayı hayatını kaybettiği, her yıl da 2,78 milyondan fazla insanın iş kazası veya meslek hastalıklarından dolayı hayatını kaybettiği, yaklaşık 374 milyondan fazla ölümle sonuçlanmayan iş kazasının olduğu ve ortalama 4 günden fazla işe devamsızlığın ortaya çıtığı rapor edilmektedir [6].

SGK verilerinde Türkiye için en güncel veri olarak 2019 yılı yer almakta ve bu yıl için 21 'sı kadın, 1216'sı erkek olmak üzere toplam 1147 çalışanın iş kazası nedeniyle hayatını kaybettiği rapor edilmiştir [7].

İş kazaları sonucunda ölüm, meslek hastalığı ve yaralanmalar meydana gelmekte ve bunlar da beraberinde maddi maliyetlere neden olmaktadır. Bu maliyetleri çalışanlara olan maliyetler, işverenlere olan maliyetler ve devlete olan maliyetler olarak ele alan çalışmalara rastlanmaktadır [5], [8-11]. İşçilere maliyet açıcından en acı olan ölümle sonuçlanandır. İş kazaları veya meslek hastalıkları sonucunda işçilerin çalışma gücünün kısmen ya da tamamen kaybolması da ortaya çıkabilmektedir. Bunun yanında iş kazaları ve meslek hastalıkları çalışanlarda hem psikolojik hem de sosyolojik sonuçlar doğurabilmekte, gerek tedavi için gerekse de gelir kaybından kaynaklı ekonomik zorluklar ortaya çıkabilmektedir. İş kazalarının işverenler açısından da önemli maliyetlere sebep olduğu literatürde yer almaktadır. Bu maliyetlerin başında iş kazalarından kaynaklı işletmelerde verimlilik kaybının ortaya çıkması gelmektedir. İş kazası sonucunda işverenlerin işletmelerinde ortaya çıkan maddi kayıplara ilaveten gerek çalışana gerekse de devlete karşı maddi yükümlülükleri de ortaya çıkabilmektedir. İş kazalarını önlemek için katlanılan maliyetler de işverenin katlandığı maliyetlerdendir.

İş kazalarının işçi ve işverene olan bu maliyetlerinin yanında devlete yani ulusal ekonomiye de bir maliyeti olmaktadır. İş kazası veya meslek hastalığından kaynakı SGK harcamaları nedeniyle ortaya çıkan giderler ile ilgili sağlık kurumu ve bu kurumlarda çalışan personelin meşguliyeti, malzeme maliyetleri, vergi kayıpları gibi önemli maliyetler de ortaya çıkmaktadır. 
İş sağlığı ve güvenliği ile ilgili olarak işyerlerinin tehlike ve risk analizlerinin erkenden analiz edilmesi ve gerekli önleyici tedbirlerin uygulanması ile işyerinin büyüklük ya da küçüklüğüne bakılmaksızın o oranda işletme hedefleri ve başarısı gerçekleştirilebilir. Bu nedenle işyerlerinde iş kazaları ve meslek hastalıklarından korunmak için etkin iş sağlı̆̆ ve güvenliği planları oluşturulmalı ve bu planların sürekli kontrol edilerek revize edilmesi gerekmektedir. İş sağlığı ve güvenliğine ilişkin her türlü düzenlemede 6331 sayılı İş Sağlığı ve Güvenliği Kanununun dikkate alınması ve kanunda belirlenen şartların/standartların yerine getirilmesi gerekmektedir [12]. İş sağllğı ve güvenliği konusunda gerekli tedbirleri alan işletmeler, iş kazası ve meslek hastalıklarının maliyetlerini azaltarak karlılıklarını arttırabilmektedirler [13]. Literatürde yer alan çalışmalar iş sağllğ iş kazaları ve meslek hastalıklarının maliyetlerinde önemli derecede düşüşlere neden olduğunu göstermektedir [5]

Yapılan bu çalışmanın amacı iş kazası ve meslek hastalığı nedeniyle Düzce Kamu Hastaneler Birliği Hastanelerinden $(\mathrm{KHBH})$ yararlanan özel sektör çalışanlarının iş kazası ve meslek hastalığı olarak öne çıkan rahatsızlıklarını belirlemek ve iş kazası ve meslek hastalıklarının hastaneye, işletmeye ve bireye yüklenen maliyetlerini ortaya çıkarmaktır.

\section{MATERYAL VE YÖNTEM}

\section{A. ARAŞTIRMA MATERYALI}

Çalışma materyalini 2010-2014 yılları arasında Düzce KHBH'lerine iş kazası ve meslek hastalığı şikâyeti ile müracaat eden hastalar oluşturmaktadır.

Çalışma kapsamında Düzce Üniversitesi Klinik Araştırmalar Etik Kurulundan 03/03/2015 tarih ve 2015/6 Karar no ile Düzce KHBH'de bu tür bir bilimsel çalışma yapılmasında “Etik ve Bilimsel Sakınca Bulunmadığını" belirtilen Etik Kurul İzin Belgesi alınmıştır.

Çalışma amaçlarına ulaşmak için 11.04.2015-15.06.2015 tarihleri arasında 2010-2014 yılları arasında Düzce KHBH'den iş kazası ve meslek hastalığı şikâyeti ile gelen hastalara ait;

- Hastaların neden KHBH’sine başvurdukları,

- Hastanın cinsiyeti,

- Hastanın yaşı,

- Hastaneye başvuru tarihi, başvuru saati, hastaneden çıkış saati,

- Hastanenin SGK'na hastaya ait fatura tutarları,

- Hastaya rapor düzenlendiyse rapor süresi ve

- Hastaların hastanede toplam kalış sürelerine ait veriler alınmıştır.

\section{A. 1. Araştırma Yöntemi}

İş kazası ve meslek hastalığı şikâyeti ile KHBH'ne müracaat eden hastaların Hasta Kayıt Formunda hastaneye müracaat etme nedenleri irdelenmiş ve el-kol yaralanmaları, ayak-bacak yaralanmaları, kafa yaralanmaları, göz yaralanmaları, göğüs yaralanmaları ve diğer yaralanmalar olmak üzere 6 alt boyutta değerlendirilmesi yapılmıştır.

Çalışma kapsamında iş kazası ve meslek hastalı̆̆ şikâyetlerinin hastaneye, işletmeye ve bireye maliyetleri hesaplanırken; "Hastaya rapor düzenlendiği günkü brüt günlük asgari ücret ile almış olduğu rapor gün sayısı çarpılıp, çıkan sonucun üçte ikisi tutarında geçici iş göremezlik ödeneği Sosyal Güvenlik Kurumunca hastaya ödeme yapılır [14] olgusundan hareketle hesaplamalar yapılmıştır.

\section{A. 2. Araştırma Bulguları}

2010-2014 yılları arasında Düzce İli KHBH Genel Sekreterliğine bağlı hastanelerde iş kazasına maruz kaldığını belirterek KHBH'ne müracaat eden hasta sayısı 1.717 olarak tespit edilmiştir (Tablo 1). İş 
kazası gerekçesiyle müracaat eden hastaların \%91,6's1 erkek, \%8,4'ünün kadın olduğu belirlenmiştir. Aynı yıllar arasında Düzce KHBH'ne meslek hastalığ şikâyeti ile ilgili 57 müracaat olduğu ve bunların \%50,9'unun kadın, \%49,1'inin de erkek olduğu belirlenmiştir (Tablo 1). Bekâr ve arkadaşları (2017) tarafından yapılan çalışmada 2005-2014 yılları arasında toplam 990.587 iş kazasının meydana geldiği ve 12.617 çalışanın hayatını kaybettiği belirlenmiştir. İlgili dönemde 5.709 çalışanın meslek hastalığına yakalandığı ve bunlardan 56'sının hayatını kaybettiği tespit edilmiştir [15].

Tablo 1. Düzce KHBH'ne iş kazası ve meslek hastalı̆̆ nedeniyle müracaat edenlerin yıllar itibarlyla dăğlımı.

\begin{tabular}{cccccc}
\hline \multirow{2}{*}{ Yıl } & $\begin{array}{c}\text { Acil servise } \\
\text { müracaat eden } \\
\text { hasta sayısı }\end{array}$ & Sayı & Yüzde & Sayı & Yüzde \\
\cline { 3 - 6 } & 58.409 & 135 & 0,23 & 3 & 0,00005 \\
\hline 2010 & 59.190 & 269 & 0,45 & 40 & 0,00068 \\
\hline 2011 & 62.987 & 317 & 0,50 & 8 & 0,00013 \\
\hline 2012 & 64.994 & 503 & 0,77 & 4 & 0,00006 \\
\hline 2013 & 67.132 & 493 & 0,73 & 2 & 0,00003 \\
\hline 2014 & $\mathbf{3 1 2 . 7 1 2}$ & $\mathbf{1 . 7 1 7}$ & & $\mathbf{5 7}$ & \\
\hline Toplam & &
\end{tabular}

Çalışma sonucunda ulaşılan verilere göre her geçen yıl iş kazasından kaynaklı olarak Düzce KHBH'ne müracaat eden hasta sayısında artış meydana gelmektedir. Bekâr ve arkadaşları (2017) tarafindan yapılan çalışmada ise 2005 yılından 2012 yılına kadar iş kazası bildirimlerinin azaldığı ancak 2013 ve 2014 yıllarında iş kazası bildirimlerinde büyük oranda artışların olduğu belirtilmiştir [15]. Akyüz ve arkadaşları (2016) tarafindan 2011-2014 yılları arasında imalat sanayisi içerisinde yer alan alt sektörlerin iş kazası istatistiklerinin incelendiği çalışmada makine ve teçhizat üretimi yapılan sektörün en yüksek oranda iş kazası, sürekli iş görmezlik ve ölüm oranlarında önde olan sektör olduğu belirtilmiştir. Bunun yanında iş kazası sıklık oranı ve iş kazası ağırlık oranlarında ise metalik olmayan ürünlerin imalatı sektörünün ilk sırada yer aldığı belirtilmiştir. Çalışma kapsamında irdelenen 20112014 yılları arasında orman ürünleri sanayi sektörü genelinde her yıl ölüm olayının gerçekleştiği tespit edilmiştir. Sektörde iş kazası sayısında yıllara bağlı olarak bir artışın olduğu da belirtilmiştir [16].

Çalışma kapsamında 2010-2014 yılları arasında iş kazası nedeniyle Düzce KHBH'ne müracaat edenlerin yaş dağılımlarına ait bulgular Tablo 2'de gösterilmiştir.

Tablo 2. Düzce KHBH’ne iş kazası ve meslek hastalı̆̆ı nedeniyle müracaat edenlerin yaş dă̆llımları (20102014).

\begin{tabular}{lcccccc}
\hline \multirow{2}{*}{ Yaş Aralı̆̆ı } & \multicolumn{2}{c}{ İş kazası } & \multicolumn{2}{c}{ Meslek hastalı̆̆ı } & \multicolumn{2}{c}{ Toplam } \\
\cline { 2 - 7 } & Sayı & Yüzde & Sayı & Yüzde & Sayı & Yüzde \\
\hline 17-20 yaş arası & 103 & 6,0 & 1 & 1,8 & 104 & 5,9 \\
\hline 21-25 yaş arası & 603 & 35,1 & 4 & 7,0 & 607 & 34,2 \\
\hline 26-30 yaş arası & 534 & 31,1 & 10 & 17,5 & 544 & 30,7 \\
\hline 31-35 yaş arası & 345 & 20,1 & 10 & 17,5 & 355 & 20,0 \\
\hline 36 yaş ve üzeri & 132 & 7,7 & 32 & 56,1 & 164 & 9,2 \\
\hline Toplam & $\mathbf{1 . 7 1 7}$ & $\mathbf{1 0 0}$ & $\mathbf{5 7}$ & $\mathbf{1 0 0}$ & $\mathbf{1 . 7 7 4}$ & $\mathbf{1 0 0}$ \\
\hline
\end{tabular}

İş kazası nedeniyle müracaat edenlerin ağırlıklı olarak 21-25 yaş aralığında $(\% 35,1)$ ve 26-30 yaş aralığında $(\% 31,1)$ oldukları görülmektedir. Meslek hastalığ nedeniyle müracaat eden hastaların ise ağırlıklı olarak $(\% 56,1) 36$ yaş ve üzerinde oldukları belirlenmiştir. İş kazası sebebiyle hastaneye müracaat eden hastaların yaşlarının minimum 18 , maksimum 47 ve ortalama yaşında 28 olduğu tespit edilmiştir. Meslek hastalığı şikâyetiyle ilgili olarak da hastaların minimum 17, maksimum 55 yaşında oldukları ve ortalama yaşında 37 olduğu tespit edilmiştir.

Çalışma kapsamında 2010-2014 yılları arasında iş kazasına maruz kaldığını belirterek Düzce KHBH'ne müracaat eden hastaların, hasta kabulde kayıt işlemi yaptırıp, poliklinikte muayene olana kadar geçirdikleri süreleriyle muayenede kalış süreleri irdelendiğinde $\% 63,1$ oranında 5 dakikadan daha kısa 
sürede muayeneye başlandığı ve \%69 oranında da 5 dakikadan daha kısa süre muayenede kaldıkları belirlenmiştir. Veriler irdelendiğinde iş kazası nedeniyle hastaneye müracaat eden hastaların \%57,5'inin hastanede en fazla 10 dakika kaldıkları hesaplanmıştır (Tablo 3).

Tablo 3. İş kazası nedeniyle müracaat eden hastaların muayene olana kadar hastanede ve poliklinikte geçirdikleri süreler.

\begin{tabular}{|c|c|c|c|c|c|c|c|}
\hline \multirow[t]{2}{*}{ Süreler } & \multicolumn{2}{|c|}{$\begin{array}{c}\text { Muayeneye } \\
\text { kadar geçen Süre }\end{array}$} & \multicolumn{2}{|c|}{$\begin{array}{l}\text { Poliklinikte } \\
\text { Kalış Süresi }\end{array}$} & \multirow{2}{*}{$\begin{array}{l}\text { Hastanede Kalış } \\
\text { Süresi }\end{array}$} & \multirow[t]{2}{*}{ Sayı } & \multirow[t]{2}{*}{ Yüzde } \\
\hline & Sayı & Yüzde & Sayı & Yüzde & & & \\
\hline $1-5 \mathrm{dk}$ arası & 1.083 & 63,1 & 1.185 & 69,0 & 1-10 dakika arası & 988 & 57,5 \\
\hline $6-10 \mathrm{dk}$ arası & 317 & 18,5 & 50 & 2,9 & 11-20 dakika arası & 175 & 10,2 \\
\hline $11-20 \mathrm{dk}$ arası & 178 & 10,4 & 45 & 2,6 & 21-30 dakika arası & 64 & 3,7 \\
\hline $21-30 \mathrm{dk}$ aras1 & 51 & 3,0 & 49 & 2,9 & 31-40 dakika arası & 59 & 3,4 \\
\hline $31-40 \mathrm{dk}$ arası & 37 & 2,2 & 38 & 2,2 & 41-50 dakika arası & 49 & 2,9 \\
\hline $41-50 \mathrm{dk}$ arası & 9 & 0,5 & 52 & 3,0 & 51-60 dakika arası & 41 & 2,4 \\
\hline $51-60 \mathrm{dk}$ arası & 10 & 0,6 & 31 & 1,8 & 61-120 dakika arası & 182 & 10,6 \\
\hline $61-120 \mathrm{dk}$ aras1 & 26 & 1,5 & 148 & 8,6 & 121-180 dakika aras1 & 85 & 5,0 \\
\hline $121 \mathrm{dk}$ ve üzeri & 6 & 0,3 & 119 & 6,9 & 181-240 dakika aras1 & 32 & 1,9 \\
\hline Toplam & 1.717 & 100 & 1.717 & 100 & 241 dakika ve üzeri & 42 & 2,4 \\
\hline
\end{tabular}

Hastaların muayene olana kadar ortalama 8 dakika 14 saniyede muayene oldukları hesaplanmıştır. Yapılan incelemeler sonucunda sürenin kısa olmasında etkili olan faktör, iş kazası nedeniyle acil servise gelen hastaların öncelikli olarak travma birimine yönlendirilmesi ve bu hastalar muayene olurken aynı zamanda kayıt işlemlerinin de yapılmasıdır.

Yapılan hesaplamalar sonucunda hastaların ortalama 29 dakika 50 saniye poliklinikte tedavi gördükleri ve ortalama 38 dakika 2 saniye de hastanede kaldıkları belirlenmiştir.

2010-2014 yılları arasında meslek hastalığı nedeniyle Düzce KHBH'ne başvuran hastaların, hasta kabulde kayıt işlemi yaptırıp, poliklinikte muayene olana kadar geçirdikleri süreler ile poliklinikte kalış sürelerine ait bulgular Tablo 4'de gösterilmiştir.

Tablo 4. Meslek hastalığı şikâyetiyle gelen hastaların muayene olana kadar hastanede geçirdikleri süreler.

\begin{tabular}{ccccccc}
\hline \multirow{2}{*}{ Süreler } & \multicolumn{2}{c}{$\begin{array}{c}\text { Muayene } \\
\text { olana kadar } \\
\text { geçirilen süre }\end{array}$} & \multicolumn{2}{c}{$\begin{array}{c}\text { Hastaların } \\
\text { poliklinikte } \\
\text { kalış süreleri }\end{array}$} & \multicolumn{2}{c}{$\begin{array}{c}\text { Hastanede toplam } \\
\text { kalış süresi }\end{array}$} \\
\cline { 2 - 8 } & Sayı & Yüzde & Sayı & Yüzde & Sayı & Yüzde \\
\hline 60 dakikadan az & 22 & 38,6 & 28 & 49,1 & 10 & 17,5 \\
\hline 61-120 dakika arası & 27 & 47,4 & 11 & 19,3 & 20 & 35,2 \\
\hline 121-180 dakika arası & 6 & 10,5 & 5 & 8,8 & 6 & 10,5 \\
\hline 181-300 dakika arası & 2 & 3,5 & 13 & 22,8 & 21 & 36,8 \\
\hline Toplam & $\mathbf{5 7}$ & $\mathbf{1 0 0}$ & $\mathbf{5 7}$ & $\mathbf{1 0 0}$ & $\mathbf{5 7}$ & $\mathbf{1 0 0}$ \\
\hline
\end{tabular}

2010-2014 yılları arasında meslek hastalığı şikâyeti ile Düzce KHBH'ne müracaat eden hastaların hasta kabul biriminde sıra alma işlemini yaptırıp, poliklinikte muayene olana kadar geçirdikleri süreler incelendiğinde 1 dakika ile 3 saat 34 dakika arasında bekledikleri tespit edilmiştir. Hastaların \%47,4'ü 1 saat ile 2 saat arasında muayene olana kadar zaman harcarken, hastaların ortalama 1 saat 18 dakika 28 saniye muayene olana kadar zaman geçirdiği hesaplanmıştır. 2010-2014 yılları arasında incelenen hastane kayıtlarına göre hastaların 1 dakika ile 6 saat 14 dakika arasında poliklinikte muayene için zaman geçirdikleri tespit edilmiştir. Hastaların \%49,1'inin poliklinikte 1 saatten daha az bir sürede muayene oldukları belirlenmiştir.

İrdelemeler sonucunda hastaların ortalama 1 saat 29 dakika 25 saniye poliklinikte muayene için zaman 
harcadıkları hesaplanmıştır. Meslek hastalığg ile Düzce KHBH'ne şikâyet eden hastaların 1 dakika ile 8 saat 18 dakika arasında hastanede kaldıkları tespit edilirken, hastaların ortalama 2 saat 47 dakika 54 saniye hastanede kaldıkları hesaplanmıştır.

2010-2014 yılları arasında iş kazasına maruz kaldığını belirterek Düzce KHBH'ne müracaat eden hastaların hastaneye başvurma nedenlerine ait bulguları Tablo 5'de gösterilmiştir.

Tablo 5. Iş kazası nedeniyle hastaların hastaneye başvurma nedenleri.

\begin{tabular}{lcccccc}
\hline \multirow{2}{*}{ Konulan tanı } & \multicolumn{7}{c}{ Cinsiyet } \\
\cline { 2 - 7 } & \multicolumn{2}{c}{ Erkek } & \multicolumn{2}{c}{ Kadın } & \multicolumn{2}{c}{ Toplam } \\
\cline { 2 - 7 } & Sayı & Yüzde & Sayı & Yüzde & Sayı & Yüzde \\
\hline El-kol yaralanması & 887 & 56,4 & 77 & 53,5 & 964 & 56,1 \\
\hline Ayak-bacak yaralanması & 465 & 29,5 & 40 & 27,7 & 505 & 29,4 \\
\hline Kafa yaralanması & 131 & 8,3 & 15 & 10,4 & 146 & 8,5 \\
\hline Göz yaralanması & 39 & 2,5 & 5 & 3,5 & 44 & 2,6 \\
\hline Göğüs yaralanmas1 & 37 & 2,4 & 4 & 2,8 & 41 & 2,4 \\
\hline Diğgr yaralanmalar & 14 & 0,9 & 3 & 2,1 & 17 & 2,3 \\
\hline \multicolumn{1}{c}{ Toplam } & $\mathbf{1 . 5 7 3}$ & $\mathbf{1 0 0}$ & $\mathbf{1 4 4}$ & $\mathbf{1 0 0}$ & $\mathbf{1 . 7 1 7}$ & $\mathbf{1 0 0}$ \\
\hline \multicolumn{1}{c}{} & & & & & &
\end{tabular}

2010-2014 yılları arasında Düzce KHBH'ne iş kazası ile müracaat eden hastaların \%56,4'ünün el ya da kol yaralanmalarından kaynaklı şikâyetle müracaat ettikleri belirlenmiştir. El-kol yaralanmalarını ayak ya da bacak yaralanmaları izlemektedir. Cinsiyet bakımından irdelendiğinde de el-kol yaralanmaları hem erkeklerde hem de kadınlarda en fazla görülen iş kazası olarak tespit edilmiştir. Bütüner ve Uzun (2010) tarafından yapılan çalışmada Türkiye'de iş kazaları sonucunda olan yaralanmaların \%53,4'ünün üst ekstremitelerde olduğu belirlenmiştir. Aynı çalışmada kaza sonucunda meydana gelen yaralanmalarda özellikle yüzeysel yaralanmaların ve açık yaraların $\% 45,6$ oranda görüldüğü ve büyük bir oranda da kazaların hafif yaralanma ile sonuçlandığı belirtilmiştir [17].

Sevim Korkut ve Gedik (2010) tarafından yapılan çalışmada Düzce orman ürünleri sanayisinde iş kazaları sonucunda çalışanların en yüksek oranda maruz kaldıkları rahatsızlıklar sırt ve bel ağrısı, baş ve boyun ağrısı, ayak ve bilek ağrısı ile yaygın olarak ağrı şikâyetleri şeklinde sıralanmıştır [18].

Gedik ve İlhan (2014) tarafından Sakarya ili mobilya işletmelerinde çalışanların iş kazası istatistiklerinin incelendiği çalışmada çalışanların ağırlıklı olarak el ve parmakta kesilme/delinme ile kas ezilmesi-lif kesilmesinden kaynaklı bir kaza geçirdikleri belirlenmiştir [19].

2010-2014 yılları arasında Düzce KHBH'ne meslek hastalı̆̆ı şikâyeti ile müracaat eden hastaların müracaat etme nedenleri Tablo 6'da gösterilmiştir.

Tablo 6. Meslek hastalı̆̆ı nedeniyle hastaların hastaneye başvurma nedenleri.

\begin{tabular}{ccccccc}
\hline \multirow{2}{*}{ Meslek hastalı̆̆ı } & \multicolumn{9}{c}{ Cinsiyet } \\
\cline { 2 - 7 } & \multicolumn{2}{c}{ Erkek } & \multicolumn{2}{c}{ Kadın } & \multicolumn{2}{c}{ Toplam } \\
\cline { 2 - 7 } & Sayı & Yüzde & Sayı & Yüzde & Sayı & Yüzde \\
\hline El-kol hastalıkları & 23 & 82,1 & 24 & 82,8 & 47 & 82,5 \\
\hline Ayak-bacak hastalıkları & 3 & 10,7 & 5 & 17,2 & 8 & 14,0 \\
\hline Diğgr hastalıklar & 2 & 7,2 & - & - & 2 & 3,5 \\
\hline Toplam & $\mathbf{2 8}$ & $\mathbf{1 0 0}$ & $\mathbf{2 9}$ & $\mathbf{1 0 0}$ & $\mathbf{5 7}$ & $\mathbf{1 0 0}$ \\
\hline
\end{tabular}

2010-2014 yılları arasında meslek hastalığı ile Düzce KHBH'ne müracaat edenlerin \%82,5'inin el-kol hastalıklarından kaynaklı hastanelere müracaat ettikleri belirlenmiştir. İş kazasına maruz kaldığını belirterek Düzce KHBH'ne müracaat eden hastaların hastaneye başvuruları sonrası SGK kayıtlarına göre oluşan poliklinik maliyetleri Tablo 7'de gösterilmiştir. 
Tablo 7. İ̧̧ kazası ve meslek hastalı̆̆ı nedeniyle başvuran hastaların SGK'na poliklinik maliyetleri.

\begin{tabular}{lcccc}
\hline \multirow{2}{*}{ Hastanın hastaneye maliyetleri } & \multicolumn{2}{c}{ İs kazası } & \multicolumn{2}{c}{ Meslek hastalı̆̆ı ${ }^{*}$} \\
\cline { 2 - 5 } & Sayı & Yüzde & Sayı & Yüzde \\
\hline 1-49,99 TL arası & 840 & 48,9 & 30 & 52,6 \\
\hline 50,00-99,99 TL arası & 526 & 30,6 & 14 & 24,6 \\
\hline 100,00-199,99 TL arası & 286 & 16,7 & 8 & 14,0 \\
\hline 200,00-299,99 TL arası ${ }^{*}$ & 35 & 2,0 & 5 & 8,8 \\
\hline 300,00-399,99 TL arası & 5 & 0,3 & & \\
\hline 400,00 TL ve üzeri & 25 & 1,5 & & \\
\hline
\end{tabular}

${ }^{*}$ Meslek hastalığında hastane maliyetlerinde 200 TL ve üzeri tek bir grup yapılmıştır.

2010-2014 yılları arasında iş kazasına maruz kaldığını belirterek KHBH'ne müracaat eden hastaların poliklinik maliyetleri hesaplanırken hastalara yapılan tetkikler (kan tahlilleri gibi), röntgen, tomografi ve MR işlemleri dikkate alınmıştır. Bu işlemler için acil servise müracaat eden hastaların SGK'na maliyeti hesaplanırken hizmet başına ödeme esas alınarak hesaplama yapılmıştır. Yapılan incelemeler sonucunda minimum 15,50 TL, maksimum 1.146,00 TL poliklinik maliyetinin oluştuğu hesaplanmıştır. Hastaların \%48,9'unun 49,99 TL'den daha az poliklinik maliyeti oluşturduğu görülmektedir. Çalışma kapsamında iş kazasına maruz kaldığını beyan eden hastalar için ortalama poliklinik maliyeti 75,20 TL olarak hesaplanmıştır.

Meslek hastalı̆̆ 1 şikâyetiyle müracaat eden hastaların Düzce KHBH'ne poliklinik maliyetleri incelendiğinde minimum 15,50 TL, maksimum da 595,90 TL poliklinik maliyetinin oluştuğu ve ortalama maliyetinde 75,61 TL olduğu hesaplanmıştır. Hastaların \%52.6'sında 49,99 TL'den daha az poliklinik maliyetinin oluştuğu görülmüştür.

2010-2014 yılları arasında iş kazasına maruz kaldığını belirterek Düzce KHBH'nde muayene olan hastalara verilen raporlarla ilgili bulgular Tablo 8'de gösterilmiş̧tir.

Tablo 8. Işs kazası nedeniyle müracaat eden hastalara verilen rapor gün sayılart.

\begin{tabular}{lcccccc}
\hline \multirow{2}{*}{ Rapor Gün Sayısı } & \multicolumn{2}{c}{ Erkek } & \multicolumn{2}{c}{ Kadın } & \multicolumn{2}{c}{ Toplam } \\
\cline { 2 - 7 } & Sayı & Yüzde & Sayı & Yüzde & Sayı & Yüzde \\
\hline Rapor verilmemiş & 78 & 5,0 & 6 & 4,2 & 84 & 4,9 \\
\hline 1 gün & 167 & 10,6 & 16 & 11,1 & 183 & 10,7 \\
\hline 2-3 gün & 693 & 44,1 & 57 & 39,6 & 750 & 43,7 \\
\hline 4-7 gün & 453 & 28,8 & 44 & 30,6 & 497 & 28,9 \\
\hline 10-30 gün & 182 & 11,6 & 21 & 14,6 & 203 & 11,8 \\
\hline Toplam & $\mathbf{1 . 5 7 3}$ & $\mathbf{1 0 0}$ & $\mathbf{1 4 4}$ & $\mathbf{1 0 0}$ & $\mathbf{1 . 7 1 7}$ & $\mathbf{1 0 0}$ \\
\hline
\end{tabular}

İş kazası nedeniyle Düzce KHBH'ne müracaat eden hastaların \%4,9'una herhangi bir rapor izni verilmezken, \%43,7'sine 2-3 gün rapor izni düzenlendiği belirlenmiştir. Yapılan hesaplamalar sonucunda iş kazası nedeniyle hastalara ortalama 4 gün rapor düzenlendiği belirlenmiştir. Gedik ve Sevim Korkut (2011) tarafindan yapılan bir çalışmada meydana gelen iş kazaları sonucu çalışanlarda kalıcı sakatlıkların ortaya çıktığı (\%17) ve iş kazası sonrası aktif işe dönme süresinin de hemen (\%6) ve 45 gün (\%17) arasında değiştiği belirtiliştir [20].

2010-2014 yılları arasında meslek hastalığı şikâyeti ile Düzce KHBH'nde muayene olan hastalara verilen raporlarla ilgili bulgular Tablo 9'da gösterilmiştir. 
Tablo 9. Meslek hastalığı nedeniyle müracaat eden hastalara verilen rapor gün sayıları.

\begin{tabular}{lcccccc}
\hline \multirow{2}{*}{ Rapor Gün Sayısı } & \multicolumn{2}{c}{ Erkek } & \multicolumn{2}{c}{ Kadın } & \multicolumn{2}{c}{ Toplam } \\
\cline { 2 - 7 } & Sayı & Yüzde & Sayı & Yüzde & Sayı & Yüzde \\
\hline 1-5 gün & 17 & 45,9 & 20 & 54,1 & 37 & 64,9 \\
\hline 6-10 gün & 8 & 53,3 & 7 & 46,7 & 15 & 26,3 \\
\hline 11-30 gün & 3 & 60,0 & 2 & 40,0 & 5 & 8,8 \\
\hline Toplam & $\mathbf{2 8}$ & $\mathbf{4 9 , 1}$ & $\mathbf{2 9}$ & $\mathbf{5 0 , 9}$ & $\mathbf{5 7}$ & $\mathbf{1 0 0}$ \\
\hline
\end{tabular}

Meslek hastalığg nedeniyle Düzce KHBH'nde tedavi gören hastalara \%64,9 oranında 1-5 gün arası rapor düzenlendiği belirlenmiştir. Meslek hastalığı nedeniyle başvuran hastalara ortalama 7 gün rapor tanzim edildiği hesaplanmıştır.

Yapılan incelemeler sonucunda meslek hastalığı nedeniyle müracaat eden erkek hastaların kadınlara göre daha fazla rapor aldıkları belirlenmiştir. Meslek hastalığı nedeniyle düzenlenen ortalama rapor gün sayısının iş kazası için belirlenen ortalama rapor gün sayısından fazla olduğu da görülmüştür.

5510 sayılı Sosyal Sigortalar ve Genel Sigortası Kanunu uyarınca; "hastalık nedeniyle geçici iş göremezliğe uğrayan sigortalıya iş göremezliğin başladığı tarihten önceki bir yıl içinde en az doksan gün kısa vadeli sigorta primi bildirilmiş olması şartıyla geçici iş göremezliğin üçüncü gününden başlamak üzere her gün için "Yatarak tedavilerde günlük kazancının yarısı, ayaktan tedavilerde ise günlük kazancın üçte ikisi tutarında geçici iş göremezlik ödeneği Sosyal Güvenlik Kurumunca ödenmektedir". Dolayısıyla hastalık nedeniyle sigortalının istirahatli olduğu iki günlük süre için kurumca iş göremezlik ödeneği ödenmediği gibi, işvereni tarafından ücret ödeme gibi bir mecburiyet de bulunmamaktadır.

Çalışma kapsamında hastalara verilen raporların maliyet hesaplanmasında "Hastaya rapor düzenlendiği günkü brüt günlük asgari ücret ile almış olduğu rapor gün sayısı çarpılıp, çıkan sonucun üçte ikisi tutarında geçici iş göremezlik ödeneği Sosyal Güvenlik Kurumunca hastaya ödeme yapılır [14] hükmünce değerlendirmeler yapılmış ve ilgili olan yılın asgari ücreti dikkate alınarak hesaplamalar yapılmış ve bulguları Tablo 10'da gösterilmiştir.

Tablo 10. SGK tarafindan ödenen geçici iş göremezlik ödeneği maliyetleri.

\begin{tabular}{|c|c|c|c|c|c|}
\hline \multirow{2}{*}{ Rapor maliyeti } & \multicolumn{2}{|c|}{ İş kazası } & \multirow[t]{2}{*}{ Rapor maliyeti } & \multicolumn{2}{|c|}{ Meslek hastalığı } \\
\hline & Sayı & Yüzde & & Sayı & Yüzde \\
\hline $0-74,99 \mathrm{TL}$ aras1 & 526 & 30,6 & $1-50$ TL aras1 & 6 & 10,5 \\
\hline $75,00-149,99$ TL aras1 & 642 & 37,4 & 51-100 TL aras1 & 8 & 14,0 \\
\hline $150,00-299,99$ TL aras1 & 412 & 24,0 & 101-150 TL aras1 & 19 & 33,3 \\
\hline $300,00 \mathrm{TL}$ ve üzeri & 137 & 8,0 & $151-200 \mathrm{TL}$ aras1 & 6 & 10,5 \\
\hline & & & 201 TL ve üzeri & 18 & 31,6 \\
\hline
\end{tabular}

İş kazası nedeniyle düzenlenen raporlarda maliyetlerin en fazla \%37,4 ile 75-149,99 TL arasında oluştuğu belirlenirken, rapor düzenlenen hastalara ortalama 130,34 TL rapor maliyeti hesaplanmıştır.

Meslek hastalığ 1 nedeniyle düzenlenen raporlarda 101-150 TL arasında oluşan rapor maliyetinin en yüksek oranda $(\% 33,3)$ oluştuğu hesaplanırken, meslek hastalığı nedeniyle hastalara ortalama 208,58 TL rapor maliyeti hesaplanmıştır.

İş kazası ve meslek hastalığı nedeniyle Düzce KHBH'ne müracaat eden hastaların işyerlerine, SGK'na ve topluma yani müracaat eden hastalara olan maliyetleri Tablo 11'de verilen eşitliklerden yararlanılarak hesaplanmıştır. 
Tablo 11. Iş̧ kazası ve meslek hastalığının maliyetleri.

\begin{tabular}{|c|c|c|}
\hline Hesap türü & Eşitlik & Açıklama \\
\hline $\begin{array}{l}\text { Rapor maliyetlerinin } \\
\text { işçiye maliyeti }\left(\mathrm{M}_{\mathrm{işçi}}\right)\end{array}$ & $M_{\text {İşçi }}=R_{i} * A \ddot{U}_{\text {İşçi }}$ & $\begin{array}{l}\mathrm{R}_{\mathrm{i}} \text { : Hastalara düzenlenen rapor gün sayıs1 } \\
\mathrm{AÜ}_{\mathrm{isç̧}}: \text { Hastanın günlük asgari ücret } \\
\text { tutarının üçte ikisi }\end{array}$ \\
\hline $\begin{array}{l}\text { Rapor maliyetlerinin } \\
\text { işverene maliyeti }\left(\mathrm{M}_{\mathrm{işveren}}\right)\end{array}$ & $M_{i S ̧ V E R E N}=R_{\mathrm{I}} * A \ddot{U}_{\text {İşseren }}$ & $\begin{array}{l}\mathrm{R}_{\mathrm{i}}: \text { Hastalara düzenlenen rapor gün sayıs1 } \\
\mathrm{A} \ddot{U}_{\mathrm{issv}}: \text { Hastanın günlük asgari ücret tutarı }\end{array}$ \\
\hline $\begin{array}{l}\text { Rapor maliyetlerinin SGK } \\
\text { maliyeti }\left(\mathrm{M}_{\mathrm{SGK}}\right)\end{array}$ & $\begin{array}{c}M_{S G K}=\left(R_{\mathrm{I}} * A \ddot{U}_{\dot{\mathrm{I} s s v .}}\right) \\
+T H\end{array}$ & $\begin{array}{l}\mathrm{R}_{\mathrm{i}} \text { : Hastalara düzenlenen rapor gün sayıs1 } \\
\mathrm{AU} \ddot{\mathrm{U}}_{\text {isv }}: \text { Hastanın günlük asgari ücret tutar1 } \\
\mathrm{TH} \text { : Hastalara yapılan toplam tedavi } \\
\text { harcamas1 }\end{array}$ \\
\hline Toplam Maliyet & $T M=M_{\mathrm{I} s ̧ c ̧ i}+M_{\mathrm{I} s ̧ v .}+M_{S G K}$ & $\begin{array}{l}\text { Bu üç maliyetin toplamı toplam maliyeti } \\
\text { oluşturacaktır. }\end{array}$ \\
\hline
\end{tabular}

2010-2014 yılları arasında iş kazası nedeniyle Düzce KHBH'ne müracaat eden hastaların işyerlerine, SGK'na ve topluma yani müracaat eden hastalara olan maliyetleri Tablo 12'de gösterilmiştir.

Tablo 12. İş kazası nedeniyle müracaat eden hastalarda yıllar itibariyle oluşan maliyetler (TL).

\begin{tabular}{|c|c|c|c|c|c|}
\hline Yillar & & $M_{\text {işci }}$ & $M_{\text {ișveren }}$ & $\mathbf{M}_{\text {SGK }}$ & TM \\
\hline \multirow{3}{*}{2010} & Minimum & 16,20 & 24,30 & 40,30 & 80,80 \\
\hline & Maksimum & 169,00 & 253,50 & 721,00 & $1.143,50$ \\
\hline & Ortalama & 66,91 & 96,88 & 175,31 & 339,10 \\
\hline \multirow{3}{*}{2011} & Minimum & 17,70 & 26,55 & 40,30 & 84,55 \\
\hline & Maksimum & 531,00 & 796,50 & 994,79 & $2.322,29$ \\
\hline & Ortalama & 73,66 & 110,38 & 190,66 & 374,70 \\
\hline \multirow{3}{*}{2012} & Minimum & 19,50 & 29,25 & 49,55 & 98,30 \\
\hline & Maksimum & 627,00 & 940,50 & $1.065,20$ & $2.632,70$ \\
\hline & Ortalama & 90,17 & 135,07 & 207,21 & 432,45 \\
\hline \multirow{3}{*}{2013} & Minimum & 21,74 & 32,62 & 33,00 & 87,36 \\
\hline & Maksimum & 681,00 & $1.021,50$ & $1.798,50$ & $3.501,00$ \\
\hline & Ortalama & 92,25 & 137,98 & 217,49 & 447,72 \\
\hline \multirow{3}{*}{2014} & Minimum & 23,8 & 35,70 & 47,35 & 106,85 \\
\hline & Maksimum & 756,00 & $1.134,00$ & $1.208,70$ & $3.098,70$ \\
\hline & Ortalama & 91,98 & 137,82 & 208,34 & 438,14 \\
\hline
\end{tabular}

Yapılan hesaplamalar sonucunda iş kazası nedeniyle Düzce KHBH'ne müracaat eden hastalardan rapor almayan hastaların da olduğu görülmüştür. Hastaların aldıkları maksimum raporlu gün sayısı 30 gün olarak belirlenmiştir. Rapor maliyetlerinin işçiye maliyetleri incelendiğinde 0 TL ile 756 TL arasında değiştiği ve ortalama rapor gün sayısı olan 4 gün dikkate alındığında da ortalama maliyetin 100,8 TL olduğu hesaplanmıştır. 2021 yılı cari fiyatları ve ortalama rapor gün sayısı olan 4 gün dikkate alındığında ortalama maliyet $318 \mathrm{TL}$ olduğu hesaplanmıştır.

2010-2014 y1lları arasında iș kazasından kaynaklı olarak ișverene yansıyan maliyetler incelendiğinde minimum 24,30 TL, maksimum 1.134,00 TL, ortalama maliyet 429,44 TL olarak hesaplanmıştır. 20102014 yılları arasında iş kazasından kaynaklı işverene yansıyan maliyetlerinin 2021 yılı cari fiyatları değerlendirildiğinde; minimum 119,25 TL, maksimum 3.577,50 TL olduğu hesaplanmıştır.

2010-2014 yılları arasında iş kazasından kaynaklı olarak SGK'na yansıyan maliyetler incelendiğinde minimum 40,30 TL, maksimum 1.798,50 TL, ortalama maliyet 599,86 TL olarak hesaplanmıştır. 20102014 yılları arasında iş kazasından kaynaklı SGK'na yansıyan maliyetlerin 2021 yılı cari fiyatları üzerinden güncel maliyetleri; minimum $169,25 \mathrm{TL}$, maksimum 4.354,50 TL ve ortalama maliyet de 636,25 TL hesaplanmıştır.

2010-2014 yılları arasında iş kazasından kaynaklı olarak toplam maliyetler incelendiğinde ise minimum 
80,80 TL, maksimum da 3.098,70 TL, ortalama maliyet 536,21 TL olarak hesaplanmıştır. 2021 yılında güncel maliyetlere göre iş kazalarının maliyetleri incelendiğinde ise minimum 137,25 TL, maksimum 7.932,00 TL ve ortalama maliyet de 696,45 TL olarak tespit edilmiştir.

Bayram ve arkadaşları (2017) tarafından yapılan çalışmada iş sağlı̆̆ ve güvenliğgi kanununda belirtilen yükümlülüklerin yerine getirilmesi ile iş kazası oranlarında azalmanın olacağına ve bunun da iş kazasından kaynaklı olarak ortaya çıkacak maliyetlerin azalmasına dair bulgulara ulaşılmıştır [13].

2010-2014 yılları arasında meslek hastalığı nedeniyle Düzce KHBH'ne müracaat eden ayakta tedavi edilen hastaların işyerlerine, SGK'na ve topluma olan maliyetleri Tablo 13'de gösterilmiştir.

Tablo 13. Meslek hastalı̆̆ nedeniyle müracaat eden ve ayaktan hastalarda yıllar itibariyle oluşan maliyetler (TL).

\begin{tabular}{|c|c|c|c|c|c|}
\hline Yillar & & $\mathbf{M}_{\text {işci }}$ & $\mathbf{M}_{\text {ișveren }}$ & MSGK & TM \\
\hline \multirow{3}{*}{2010} & Minimum & 67,60 & 101,40 & 150,80 & 319,80 \\
\hline & Maksimum & 507,00 & 760,50 & 848,90 & $2.116,40$ \\
\hline & Ortalama & 297,55 & 446,32 & 530,63 & 1274,50 \\
\hline \multirow{3}{*}{2011} & Minimum & 27,90 & 27,90 & 52,10 & 107,90 \\
\hline & Maksimum & 558,00 & 877,50 & $1.432,90$ & $2.868,40$ \\
\hline & Ortalama & 115,05 & 169,18 & 250,64 & 534,87 \\
\hline \multirow{3}{*}{2012} & Minimum & 58,50 & 58,50 & 133,40 & 250,40 \\
\hline & Maksimum & 585,00 & 877,50 & $1.082,40$ & 2544,9 \\
\hline & Ortalama & 197,81 & 293,06 & 373,22 & 864,09 \\
\hline \multirow{3}{*}{2013} & Minimum & 32,62 & 32,62 & 70,82 & 136,06 \\
\hline & Maksimum & 252,00 & 378,00 & 393,50 & $1.023,50$ \\
\hline & Ortalama & 129,04 & 187,44 & 227,13 & 543,61 \\
\hline
\end{tabular}

2013 yılı 9. aydan sonra Düzce KHBH'lerine meslek hastalığı başvurusunda bulunan hastaların, meslek hastalıkları hastanelerine yönlendirildiği ve bu nedenle bu yıllara ait verilerin tutulmadığ 1 tespit edilmiştir. 2013 yılı dikkate alındığında meslek hastalığının ortalama maliyetlerinin işçilere 129,04 TL; işverenlere 187,44 TL ve SGK'na da 227,13 TL, toplam maliyet 543,61 TL olduğu belirlenmiştir.

2010-2014 yılları arasında meslek hastalığı nedeniyle Düzce KHBH'ne müracaat eden yatarak tedavi gören hastaların işyerlerine, SGK'na ve topluma olan maliyetleri Tablo 14'de gösterilmiştir.

Tablo 14. Meslek hastalı̆̆ nedeniyle müracaat eden ve yatan hastalarda yıllar itibariyle oluşan maliyetler (TL).

\begin{tabular}{clcccc}
\hline & Yllar & M $_{\text {işçi }}$ & M $_{\text {işveren }}$ & M $_{\text {SGK }}$ & TM \\
\hline \multirow{2}{*}{2010} & Minimum & 210,6 & 315,9 & 1063,73 & 1925,63 \\
\cline { 2 - 6 } & Maksimum & 574,6 & 861,9 & 1651,33 & 1967,23 \\
\cline { 2 - 6 } & Ortalama & 392,6 & 588,9 & 1357,53 & 1946,43 \\
\hline \multirow{2}{*}{2011} & Minimum & 2232 & 334,8 & 227,82 & 813,72 \\
\cline { 2 - 6 } & Maksimum & 669,6 & 1004,4 & 982,65 & 1777,84 \\
\cline { 2 - 6 } & Ortalama & 492,36 & 738,54 & 635,99 & 1514,73 \\
\hline
\end{tabular}

İncelemeler sonucunda Düzce KHBH'lerine 2012 yılında yatan hasta olmadığı belirlenmiştir. Ayrıca 2013 yılının 9. aydan itibaren de meslek hastalığı tespiti için meslek hastalığı hastanelerine hastaların yönlendirilmesinden dolayı bu yıllara ait veriler kayıtlarda tespit edilememiştir.

Meslek hastalığı nedeniyle ayaktan müracaat edenlere ortalama 12 gün rapor düzenlendiği göz önüne alındığında ortalama maliyet işçi için 208,2 TL, işveren için 312,3 TL ve SGK için de 462,200 TL olarak hesaplanmıştır. Meslek hastalığı nedeniyle ayaktan tedavi olan ve rapor düzenlenen hastalarda ortalama toplam maliyetleri irdelendiğinde 1048,70 TL olarak belirlenmiştir. 
Meslek hastalığı nedeniyle yatış yapılan hastalara ortalama 24 gün rapor düzenlendiği göz önüne alındığında ortalama maliyet işçi için 416,40 TL, işveren için 624,6 TL ve SGK için de 842,14 TL olarak hesaplanmıştır. Meslek hastalığı nedeniyle yatış yapılarak tedavi olan ve rapor düzenlenen hastalarda ortalama toplam maliyetleri irdelendiğinde 1657,59 TL olarak belirlenmiştir.

\section{IV.SONUC}

Yapılan bu çalışma ile 2010-2014 yılları arasında Düzce İli KHBH Genel Sekreterliğine bağlı hastanelere iş kazası ve meslek hastalığı nedeniyle müracaat eden hastalar irdelenmiştir. Elde edilen sonuçlara göre ilgili yıllar içerisinde iş kazası nedeniyle \%92 oranında erkekler, meslek hastalığında ise \%52 oranında kadınlar şikâyette bulunmuşlardır. İlgili yıllar içerisinde veriler irdelendiğinde hem acil servise müracaat eden hasta sayısında hem de iş kazası şikâyetiyle müracaat edenlerin sayısında göreceli de olsa bir artış olduğu tespit edilmiştir. Ancak, aynı durum meslek hastalığı için söz konusu değildir. Meslek hastalığında toplam müracaatın \%70’i 2011 yılında yapılmıştır.

Yapılan hesaplamalar sonucunda iş kazası nedeniyle müracaat edenlerin ortalama yaşları 28 olarak belirlenirken, en çok müracaatın 21-25 yaş arasındaki çalışanlardan yapıldığı belirlenmiştir. Meslek hastalığı nedeniyle müracaat eden çalışanların ise ortalama yaşları 37 olarak tespit edilirken, şikâyetlerin ağırlıklı olarak 36 ve daha fazla yaşta olan çalışanlardan geldiği belirlenmiştir.

İş kazası nedeniyle hastanelerde acil servise müracaat eden çalışanların \%63'ünün 5 dakikadan daha kısa sürede muayenesine başlandığ 1 tespit edilmiştir. İş kazası nedeniyle hastaneye müracaat eden hastaların \%57,5'inin hastanede en fazla 10 dakika kaldıkları hesaplanmıştır.

Çalışma sonucunda iş kazası ile müracaat eden hastaların yarıdan fazlasının el ya da kol yaralanmalarından kaynaklı şikâyetle geldikleri ve bunu ayak ya da bacak yaralanmalarından kaynaklı şikâyetlerin izlediği belirlenmiş̧tir.

2010-2014 yıllarında iş kazası nedeniyle hastaneye müracaat eden hastaların ortalama poliklinik maliyeti 75,20 TL hesaplanmıştır. İş kazasıyla hastaneye müracaat eden hastalara ortalama 4 gün rapor verilirken, meslek hastalığ 1 nedeniyle müracaat eden hastalara da ortalama 7 gün rapor verildiği belirlenmiştir. İş kazası nedeniyle rapor düzenlenen hastalara ortalama 130,34 TL SGK tarafından geçici iş göremezlik ödeneği ödenmiştir. Meslek hastalığı nedeniyle rapor düzenlenen hastalara ortalama 208,58 TL SGK tarafından geçici iş göremezlik ödeneği ödenmiştir.

2010-2014 yılları arasında iş kazasından kaynaklı olarak hastalara düzenlenen raporlardan dolayı rapor maliyetlerinin işçiye yansımasının 0-756 TL arasında değiştiği ve ortalama olarak da 100,8 TL olduğu hesaplanmıştır. İş kazalarından dolayı hastaneye müracaat eden çalışanların işverene yansıyan maliyetlerinin 24,30-1.134,00 TL arasında değiştiği ve ortalama olarak da 429,44 TL olduğu belirlenmiştir. Aynı yıllarda iş kazasından kaynaklı olarak SGK'na yansıyan maliyetler incelendiğinde ise 40,30-1.798,50 TL arasında değiştiği ve ortalama olarak da 599,86 TL olduğu hesaplanmıştır. Elde edilen bu verilere göre 2010-2014 yılları arasında iş kazasından kaynaklı olarak toplam maliyetler incelendiğinde ise minimum 80,80 TL, maksimum da 3.098,70 TL, ortalama maliyet 536,21 TL olduğu tespit edilmiştir.

2010-2014 yıllarında yer alan verilere göre düzenlenen ve hesaplanan bu sonuçların özellikle işletmeler açısından dikkatlice irdelenmesi ve buna bağlı olarak da işletmelerinin verimliliklerinde önemli bir etken olan iş kazası ve meslek hastalığına gerekli özeni ve önemi vermesi önerilmektedir. Özellikle işletme yöneticilerinin ve işletme sahiplerinin 6331 sayılı İş Sağlığı ve Güvenliği kanununun gerekliliklerini tam olarak yerine getirmesi gerekmektedir. 


\section{KAYNAKLAR}

[1] A. Güzel ve A. R Okur, Sosyal Güvenlik Hukuku, Yenilenmiş 4. baskı. İstanbul, Türkiye: Beta Basım Yayım Dağıtım A.Ş., 1994.

[2] A. C. Tuncay, Sosyal Güvenlik Hukuku Dersleri, Yenilenmiş 7. bask1, İstanbul, Türkiye: Beta Basım Yayım ve Dağıtımı A.Ş., 1996.

[3] L. Akın, “İş kazasından doğan maddi tazminat," Doktora tezi, Sosyal Bilimler Enstitüsü, Ankara Üniversitesi, Ankara, Türkiye, 2000.

[4] G. B. Yıldız, "İşverenin iş kazasından doğan hukuki sorumluluğu," Toprak İşveren Dergisi, s. $86,2010$.

[5] M. Koç ve N. Akbıyık, "Türkiye'de iş kazalarının maliyetleri ve çözüm önerileri," Akademik Yaklaşımlar Dergisi, c. 2, s. 2, ss. 129-175, 2011.

[6] Uluslararası Çalışma Örgütü. (1952, 28 Haziran). Sosyal Güvenlik Sözleşmesi [Çevrimiçi]. Erişim: https://www.ilo.org/global/topics/safety-and-health-at-work/lang-en/index.htm.

[7] Sosyal Güvenlik Kurumu. (2020, 1 Ocak). Sosyal Güvenlik Kurumu Yıllıkları [Çevrimiçi]. Erişim: http://www.sgk.gov.tr/wps/portal/sgk/tr/kurumsal/istatistik/sgk_istatistik_yilliklari.

[8] N. A. Akçın, ve E. Hamarat, "TTK' da meydana gelen iş kazası ve meslek hastalıklarının hukuki ve mali durumu,” Türkiye 9. Kömür Kongresi Bildiriler Kitabı, 1994, ss.151-166.

[9] G. Ofluoğlu ve F. Uysal, "İş kazaları ve meslek hastalıklarından kaynaklanan psiko-sosyal sorunların dişsal maliyeti," Кати-İ̧ İ̧̧ Hukuku ve Íktisat Dergisi, c. 5, s. 4, ss. 1-8, 2000.

[10] E. Demir, "Metal iş kolunda meydana gelen iş kazaları ve iş kazalarının oluşturduğu kayıpların ekonomik yönden analizi," Yüksek Lisans tezi, Fen Bilimleri Enstitüsü, Marmara Üniversitesi, İstanbul, Türkiye, 2009.

[11] O. Korkmaz, "İş kazaları ile verimlilik arasındaki ilişki: Türkiye Taşkömürü Kurumu örneği," Yaşar Üniversitesi Dergisi, c. 6, s. 23, ss. 3805-3813, 2011.

[12] I. Kamardeen, "E-OHS planning system for builders," Architectural Science Review, vol. 54, no. 1, pp. 50-64, 2011.

[13] M. Bayram, H. İskender ve A. Kökçam, "İmalat firmalarında iş sağlığ 1 ve güvenliği yatırım harcamaları ile kaza oranları ve iş kazası maliyetleri ilişkisi: İşletme bütçesine İSG harcamaları için kaynak tahsis edilmesinin önemi," Akademik Platform Mühendislik ve Fen Bilimleri Dergisi, c. 5, s. 3, ss. 71-81, 2017.

[14] 5510 Sayılı Sosyal Sigortalar ve Genel Sağlık Sigortası Kanunu, T.C. Resmi Gazete, Sayı: 26200, 16.06.2006.

[15] İ, O. Bekar ve E. Bekar, "İş kazası ve meslek hastalıklarının maliyeti (2005-2014)," Uluslararası Ekonomik Araştırmalar Dergisi, c. 3, s. 3, ss. 479-489, 2017.

[16] K. C. Akyüz, İ. Akyüz, T. Tugay ve T. Gedik, "Orman ürünleri sanayi sektöründe iş kazası istatistiklerine genel bir bakış," Düzce Üniversitesi Orman Fakültesi Ormancllık Dergisi, c. 12, s. 2, ss. 66-79, 2016. 
[17] O. Bütüner ve D. Uzun, "İş kazalarının maliyetleri ve hesaplamaları üzerine bir araştırma," MYO-ÖS 2010 Ulusal Meslek Yüksekokulları Öğrenci Sempozyumu, Ekim 2010, ss. 19-20.

[18] D. Sevim Korkut and T. Gedik, "A research on occupational safety in forest products industry in Turkey," African Journal of Business Management, 2010, vol. 4, no. 7, pp. 1423-1433.

[19] T. Gedik ve A. İlhan, "Sakarya ili mobilya imalatçılarında iş sağlı̆̆ 1 ve iş güvenliği üzerine bir inceleme," Türkiye Ormancllı Dergisi, c. 15, s. 2, ss. 123-129, 2014.

[20] T. Gedik ve D. Sevim Korkut, "A research on work accidents in forest products industry in Duzce," International Journal of the Physical Sciences, vol. 6, no. 30, pp. 7065-7072, 2011. 